\title{
Heterogeneous Effects of Agricultural Technical Assistance in Colombia
}

\author{
Nicolás Arturo Torres Franco ${ }^{1}$, Eleonora Dávalos ${ }^{1 \star(1)}$ and Leonardo Fabio Morales ${ }^{2}$ \\ ${ }^{1}$ Department of Economics Universidad EAFIT, Medellín, Colombia and ${ }^{2}$ Banco de la República, Colombia \\ ${ }^{*}$ Corresponding author. Email: edavalosa@eafit.edu.co
}

\begin{abstract}
Small family farms account for $72 \%$ of the farms in the world. Most of these farms, in developing countries, face labor productivity gaps. One of the strategies to increase agricultural productivity focuses on implementing technical assistance programs. Using agriculture microdata, we estimate the marginal treatment effect of receiving technical assistance services. We find that technical assistance generates heterogeneous effects. On average, agricultural units receiving technical assistance increased their agricultural production by $50.4 \%$. However, there is important heterogeneity of technical assistance's effects across the production units' unobserved and observed characteristics.
\end{abstract}

Keywords: family farms; heterogeneous effects; technical assistance

JEL Classification: Q12; Q16; Q18

\section{Introduction}

Small family farms represent around $72 \%$ of farms globally (FAO, 2014). ${ }^{1}$ In developing countries, increasing labor productivity among family farms is a pressing issue, as they face a sustained unfavorable productivity gap. As of 2013, the agricultural value-added per worker in the United States was 43 times higher, on average, than in developing countries in Africa and South America (Bank, 2021). This gap comes from poor infrastructure and low human capital accumulation in the agricultural sector (Gutierrez, 2002). In developing countries, most family farms are small farms with limited access to developed markets, public support, and credit. They are located in rural areas with low investment in public goods, such as roads, electricity, and drinkable water, contributing to low agricultural productivity.

Technology adoption is an effective way to tackle this low productivity. Analyses of the 1960s Green Revolution find a positive and significant effect of implementing improved varieties of seeds on production (Evenson and Gollin, 2003; Murgai, 2001). Other studies find indirect effects of technology adoption on productivity by accounting for a reduction in poverty in Bangladesh and Uganda (Kassie et al., 2011; Mendola, 2007), but technology adoption in a production process involves a series of complex steps (Doss, 2006). First, the producer should be aware about the technology. Then, he or she should be willing to try it out, and finally, the producer should expect positive returns from using it to adopt it (Lambrecht et al., 2014). Therefore, many technical assistance programs include technology adoption as part of them to facilitate this complex process.

\footnotetext{
${ }^{1}$ Family farms are farms operated by families with a high percentage of family labor. According to Graeub et al. (2016), 53\% of the world's production is cultivated by family farms.

(C) The Author(s) 2021. Published by Cambridge University Press on behalf of the Southern Agricultural Economics Association. This is an Open Access article, distributed under the terms of the Creative Commons Attribution-NonCommercial-ShareAlike licence (http:// creativecommons.org/licenses/by-nc-sa/4.0/), which permits non-commercial re-use, distribution, and reproduction in any medium, provided the same Creative Commons licence is included and the original work is properly cited. The written permission of Cambridge University Press must be obtained for commercial re-use.
} 
Technical assistance programs are based on knowledge transfer and provide training on new technologies to promote technology adoption. These programs are contingent on the needs of the community, but most of them include non-financial assistance-skills training, knowledge transfer, and consulting services_-aiming to enhance agricultural production. In many Latin American countries, agriculture is an important productive sector (OECD/FAO, 2019) and their economic development strategies include technical assistance programs to improve agricultural production (Egas Yerovi and De Salvo, 2018). However, there is little research on the effect of technical assistance on agricultural production in these countries (Klerkx et al., 2016). Studies evaluating the impact of public technical assistance programs are scarce (OECD, 2015). There are no studies in the literature that model selection into the treatment of technical assistance, and there is no research on the heterogeneous effects of technical assistance.

Yet, impact variation is relevant for policy design purposes, as public investments can have a greater impact when focusing on the right population (Carneiro et al., 2011). There are several studies on the heterogeneous effects of different social programs (Carneiro et al., 2011; Carneiro et al., 2017; Kline and Walters, 2016; Maestas et al., 2013; Morales et al., 2021; Noboa-Hidalgo and Urzúa, 2012), but none of these studies focus on agricultural production. Hence, here, we seek to close that knowledge gap by analyzing the effect of technical assistance programs on agricultural production in Colombia. In this study, we model the probability that an agricultural unit receives technical assistance, estimate the Marginal Treatment Effect (MTE) of technical assistance on production, and describe the heterogeneous returns from technical assistance.

Following Heckman et al. (2006), the MTE methodology extends the instrumental variables approach and allows us to test the existence of technical assistance heterogeneous effects. To do so, we use two instrumental variables: 1) exposure to armed conflict at the agricultural unit level and 2) planting cost. The first instrumental variable (IV) is based on a technical assistance program launched in 2012 by the national government. That technical assistance program targeted producers (agricultural units) located in areas with armed conflict. The second IV captures the opportunity cost of receiving technical assistance. To perform the analysis, we use micro data from the 2014 agricultural census in Colombia.

Based on our results, agricultural units that joined technical assistance programs increased their agricultural production value per hectare, on average, by $50.4 \%$ in comparison to agricultural units without technical assistance. We also find a heterogeneous effect of technical assistance. The smallest agricultural units that joined technical assistance programs increased their agricultural production value by $52 \%$; this is more than $10 \%$ points in comparison to medium-sized agricultural units. In addition, we find that if the smallest agricultural units without technical assistance had joined the program, their agricultural production value would have increased by $45 \%$. Therefore, our results show that technical assistance programs should target specifically the smallest units because there are opportunities to increase marginal benefits.

\section{Technical Assistance and Agricultural Production}

Technical assistance is a broad concept. In this study, agricultural extension and technical assistance refer to the same kind of activities focused on non-financial support to enhance agricultural production. Technical assistance includes training activities, knowledge transfer, and consulting services (DANE, 2014c). In some cases, agricultural units can receive technical assistance in more than one topic simultaneously, but most of the agricultural units in this study received training on good agricultural practices to minimize hazards in the harvest, packing, and transportation of fruits and vegetables (ICA, 2009). ${ }^{2}$

The effect of technical assistance on agricultural production is also broad and varies from one study to another. Case studies in Malawi, India, Pakistan, and Paraguay reported positive and

\footnotetext{
${ }^{2}$ Colombia follows Global G.A.P. guidelines for good agricultural practices.
} 
significant effects on agricultural production (Benyishay and Mobarak, 2018; Bravo-Ureta and Evenson, 1994; Rosegrant and Evenson, 1993), while in Indonesia, Feder, Murgai, and Quizon (2004) found no effect of farmer field schools on yield production, and Ragasa and Mazunda (2018) in Malawi found no effect of technical assistance on productivity. The main reason for this variation comes from unobserved characteristics and measurement error of technical assistance (Aker, 2011; Evenson, 2001). Therefore, here we seek to control for the main source of endogeneity - the non-random selection process of agricultural units into technical assistance programs.

\subsection{Agricultural Units and Technical Assistance Programs in Colombia}

Located in South America, Colombia is the fourth largest economy in Latin America (OECD/UN/ UNIDO, 2019). Five percentage of its gross domestic product (GDP) in 2014 comes from agriculture (DANE, 2018), and family farms dominate agricultural production. As of $2014,65 \%$ of agricultural units in Colombia used family labor in their production process and $73 \%$ had $<5$ hectares (DANE, 2014a). In Colombia, an agricultural unit is a farm dedicated to produce agricultural products. It can be composed of a fraction, one, or more fields, but it has only one owner (producer), who is responsible for productive activities within the agricultural unit (DANE, 2014c). Therefore, most of the technical assistance programs are targeted to agricultural units.

As many small farms in developing economies, agricultural units in Colombia are laborintensive and have little access to credit; $51 \%$ use fertilizers or pest controls, and only $11 \%$ applied for credit (DANE, 2014a). As a result of these and other limitations, Colombian labor productivity in the agricultural sector is 13 times less than in the United States (Bank, 2021). Thus, improving agricultural productivity is a central issue in the local policy agenda, and technical assistance programs are one of the strategies being used.

The Colombian government is the leading provider of technical assistance in the country since the 1940s (OECD, 2015). In early stages of this economic developing strategy, technical assistance was provided by municipality management units that had autonomy to design projects with public funding. In the 2000s, the government created Centros Provinciales de Gestión Agroempresarial, local agricultural management centers that designed technical assistance projects and hired services from private companies. In 2007, the national government launched Agro Ingreso Seguro (AIS). As part of this national public program, the national government delivered subsidies directly to producers to buy technical assistance services (CNCA, 2008; Ley 1133 de 2007, 2007).

Under AIS, the government also implemented three different projects to provide technical assistance: 1) Asistencia Técnica Especial, focusing on small agricultural units in vulnerable conditions, 2) Asistencia Técnica Directa Rural, targeting small and medium agricultural units, and 3) Asistencia Técnica Gremial, directed to agricultural producers' associations. Projects targeting agricultural units provided the following services: technology adoption, advice to choose productive activities, financial education, marketing, and producer organization capabilities. To access these services, each municipality designed a technical assistance plan and applied for funding. The central government selected the best projects and financed up to $80 \%$ of its total cost (MADR, 2014). This program operated during the period of study.

\section{Data}

This paper analyzes data from the Tercer Censo Nacional Agropecuario (CNA); an agricultural census conducted in 2014 that included $99 \%$ of rural Colombia. This census is the most updated and comprehensive source of information for studying the Colombian agricultural sector. The CNA collected data from agricultural units and non-agricultural units classified based on production activities developed at the time the survey was conducted. Agricultural units represent $41 \%$ of the total sample (919,512 observations). This analysis focuses on agricultural units with 
Table 1. Characteristics of agricultural units in the sample

\begin{tabular}{|c|c|c|c|c|c|}
\hline \multirow[b]{2}{*}{ Variables } & \multicolumn{2}{|c|}{$\begin{array}{l}\text { Without technical } \\
\text { assistance }\end{array}$} & \multicolumn{2}{|c|}{$\begin{array}{l}\text { With technical } \\
\text { assistance }\end{array}$} & \multirow[b]{2}{*}{ Difference } \\
\hline & Mean & Std. & Mean & Std. & \\
\hline Size agricultural units & 10.430 & 1.923 & 10.679 & 1.423 & $0.250^{\star \star \star}$ \\
\hline Permanent job & 2.381 & 3.720 & 2.670 & 5.984 & $0.289^{\star \star \star}$ \\
\hline Machinery Tenure & 0.187 & 0.390 & 0.325 & 0.468 & $0.138^{\star \star \star}$ \\
\hline Area agricultural infrastructure & 1.029 & 1.961 & 1.667 & 2.076 & $0.638^{\star \star \star}$ \\
\hline Planting cost & 12.433 & 2.053 & 13.560 & 1.801 & $1.126^{\star \star \star}$ \\
\hline Value of production per hectare & 6.236 & 0.002 & 6.144 & 0.002 & $-0.092^{\star \star \star}$ \\
\hline Observations & \multicolumn{2}{|c|}{109676} & \multicolumn{2}{|c|}{81912} & \\
\hline Number of Municipalities & \multicolumn{2}{|c|}{1034} & \multicolumn{2}{|c|}{986} & \\
\hline
\end{tabular}

Notes: An agricultural unit is a business organization dedicated to the production of agricultural products. It can be composed by one, a fraction or more fields, but it has one and only one owner (producer). Most agricultural units have one household, but in some cases, there are multiple households within an agricultural unit. ${ }^{\star \star *} \mathrm{p}<0.01$

information about agricultural production in 2013. The final sample includes 191,588 agricultural units distributed across 1,118 municipalities throughout the country. Table 1 summarizes descriptive statistics of agricultural units included in the analysis.

The CNA also includes household characteristics and information about access to technical assistance programs. Technical assistance, the main independent variable in this analysis, is a discrete variable coded one if the agricultural unit received technical assistance in 2013, zero otherwise. Technical assistance is our treatment variable. In the sample, $33.7 \%$ of agricultural units received technical assistance. Agricultural units can receive technical assistance in several topics simultaneously. Most of the agricultural units that joined technical assistance programs received training on good agricultural practices, commerce and trading, and financial education (Appendix 1 shows all types of technical assistance reported in the CNA). Table 2 presents descriptive statistics of households at agricultural units included in the analysis.

The outcome of interest in this paper is the value of agricultural production per cultivated area. To calculate this variable, we first multiplied the total quantity (in tons) of each crop by its price per ton in 2013. Then, we added up these monetary values from different crops to get an aggregate measure of production value. Finally, we divided this monetary value by the total cropped area in each agricultural unit. Equation (1) describes this calculation. $Y$ is the value of agricultural production per hectare. $q_{j}$ is the total quantity in tons of each crop $j . p_{j}$ is the price per ton of crop $j$, and $A$ is the total cropped area in each agricultural unit. This measure makes possible to compare different crops across agricultural units and controls for heterogeneity in their size.

$$
Y=\frac{1}{A} \sum_{j} q_{j} * p_{j}
$$

Because the CNA does not include data on crop price, machinery cost, input cost, planting cost, or technical assistance cost, we used other data sources. To create a production value variable at agricultural unit level, we used data from: 1) the 2013 wholesale price information from the Sistema de Información de Precios y abastecimientos del Sector Agropecuario (SIPSA) and 2) the 2013 coffee base purchase price. SIPSA has data on 73 out of 484 crops included in the CNA data set, covering 21 out of 32 states in Colombia (Appendix 2 summarizes information for 73 crops). These data have prices for the most planted crops in Colombia, such as plantain, coffee, rice, cassava, corn, and potatoes. Finally, to estimate planting cost by crop, size, and 
Table 2. Characteristics of households and head of household at agricultural units

\begin{tabular}{|c|c|c|c|c|c|}
\hline \multirow[b]{2}{*}{ Variables } & \multicolumn{2}{|c|}{$\begin{array}{l}\text { Without technical } \\
\text { assistance }\end{array}$} & \multicolumn{2}{|c|}{$\begin{array}{l}\text { With technical } \\
\text { assistance }\end{array}$} & \multirow[b]{2}{*}{ Difference } \\
\hline & Mean & Std. & Mean & Std. & \\
\hline \multicolumn{6}{|l|}{ Household } \\
\hline Average household size & 3.889 & 2.933 & 3.889 & 3.238 & 0.000 \\
\hline Percentage people older 10 & 0.866 & 0.186 & 0.870 & 0.177 & $0.005^{\star \star \star}$ \\
\hline Households victim of conflict & 0.181 & 0.382 & 0.184 & 0.384 & $0.003^{\star}$ \\
\hline Percentage of men & 0.567 & 0.249 & 0.567 & 0.235 & -0.001 \\
\hline Average years of education & 4.348 & 2.792 & 4.618 & 2.620 & $0.269^{\star \star \star}$ \\
\hline Average age & 38.425 & 17.243 & 38.017 & 16.254 & $-0.408^{\star \star \star}$ \\
\hline \multicolumn{6}{|l|}{ Head of Household } \\
\hline Percentage of men & 0.805 & 0.385 & 0.841 & 0.355 & $0.036^{\star \star \star}$ \\
\hline Years of education & 3.681 & 3.357 & 3.890 & 3.168 & $0.210^{\star \star \star}$ \\
\hline Average age & 51.267 & 15.231 & 50.652 & 14.189 & $-0.615^{\star \star \star}$ \\
\hline Observations & \multicolumn{2}{|c|}{109676} & \multicolumn{2}{|c|}{81912} & \\
\hline Number of Municipalities & \multicolumn{2}{|c|}{1034} & \multicolumn{2}{|c|}{986} & \\
\hline
\end{tabular}

Notes: An agricultural unit is a business organization dedicated to the production of agricultural products. It can be composed by one, a fraction or more fields, but it has one and only one owner (producer). Most agricultural units have one household, but in some cases, there are multiple households within an agricultural unit. ${ }^{\star \star \star} p<0.01$.

location, we used data from the Red de Información y Comunicación del Sector Agropecuario Colombiano (Agronet, 2010). The resulting sample of crops and prices represents $72.32 \%$ of the total agricultural units with crop production information and $50.9 \%$ of the total area under cultivation.

\section{Empirical Method}

Agricultural units might adopt technical assistance due to factors we cannot observe, which can correlate with observed production. This issue is known as a selection bias problem. Our first solution to this bias problem is to use an IV approach, which allows us to identify causal inferences drawn from the effect of technical assistance on agricultural production. However, this solution ignores that agricultural units can know their result of receiving technical assistance based on their idiosyncratic characteristics before being selected. The existence of sorting on gains causes IVs to identify a local effect only. To address this concern, Heckman et al. (2006) and Heckman and Vytlacil (2005) proposed a structural estimation of the MTE to improve the IV estimation. Following Carneiro et al. (2011) and Heckman et al. (2006), this paper estimates the average treatment effect (ATE), average treatment of the treated (ATT), and average treatment of the untreated (ATUT) parameters and some policy simulations based on the MTE estimation.

Agricultural units choose to enroll in technical assistance programs based on the gains they anticipate from the program and unobserved factors such as productivity. Unobserved factors determine the selection into technical assistance treatment. Therefore, this is the primary source of endogeneity into the technical assistance variable. The MTE methodology allows controlling for this source of bias in the estimation by modeling the selection process into the treatment, in this case enrolling into technical assistance programs. This methodology is a general model of sorting on gains proposed by Heckman and Vytlacil (2005). In this paper, we model the selection into 
technical assistance, correcting any endogeneity bias explained by nonrandom selection into the treatment. Finally, to avoid any additional bias arising from the omission of relevant variables, we control for agricultural unit geographical location by including means of independent variables at the vereda level. Vereda is an administrative unit in Colombian similar to census tract in the United States. This procedure is equivalent to including vereda fixed effects (Malikov and Kumbhakar, 2014).

\subsection{Structural Model}

The following equations represent the potential crop production of agricultural units, depending upon receiving technical assistance or not:

$$
\begin{aligned}
& Y_{1}=\alpha_{1}+X \beta_{1}+U_{1} \\
& Y_{0}=\alpha_{0}+X \beta_{0}+U_{0}
\end{aligned}
$$

Equation (2) illustrates the potential crop production value per hectare of agricultural units receiving technical assistance, while equation (3) represents crop production value per hectare for agricultural units not receiving assistance. In both cases, equations depend linearly on a set of observable characteristics, $X$, and unobservable characteristics, $U$. Those unobserved characteristics can affect production differently depending on whether the farm is assisted; the difference of $U_{1}-U_{0}$ represents the idiosyncratic heterogeneity of the technical assistance effect.

The decision to get technical assistance is discrete and depends on the unobserved latent variable $I$. Through a set of observed variables, $Z$, the selection equation (4) captures the technical assistance provision system's bias toward producers with better production characteristics; this equation also models those factors that we do not see, which induces producers to join the program $(V)$.

$$
D_{i v}=1[I=Z \gamma-V \geq 0]
$$

The $Z$ vector includes exclusion restrictions that influence the enrollment into technical assistance, which in our case are exposure to conflict and planting cost; these characteristics are our IVs. The assumptions of the model are the following:

$$
\begin{array}{r}
(Z, X) \perp\left(U_{1}, U_{0}, V\right) \\
\left(U_{1}, U_{0}, V\right) \sim N(0, \Sigma) \\
\text { where } \Sigma=\left[\begin{array}{ccc}
\sigma_{0}^{2} & \sigma_{1,0} & \rho_{1} \\
\sigma_{1,0} & \sigma_{1}^{2} & \rho_{2} \\
\sigma_{v, 0} & \rho_{2} & \sigma_{v}^{2}
\end{array}\right]
\end{array}
$$

The central distributional assumption is that the errors $U_{1}, U_{0}$, and $V$ are jointly normally distributed (see Heckman and Vitlacyl, 2005). The variance-covariance matrix $\Sigma$ captures the existing relation between the different unobserved factors in structural and selection equations; this captures the selection bias in the model. It also collects the differential effect of selection bias on the potential outcomes. ${ }^{3}$

\footnotetext{
${ }^{3}$ The distribution of the unobserved heterogeneity represented by $U_{1}, U_{0}, V$, is assumed to be a multivariate normal. As can be seen in equation (8), our main evaluation parameter estimate, MTE, would have a smooth distribution as well. This is a consequence of these distributional assumptions on $U_{1}, U_{0}, V$.
} 


\subsection{Marginal Treatment Effect and Average Treatment Effect Estimation}

The decision criteria can be expressed as $P(z \gamma) \geq U_{D}$, where $P(z \gamma)=\Phi(z \gamma)$ by the normality assumption. $U_{D}$ is the cumulative probability of observing a particular level of $V$. By construction, $U_{D} \sim \operatorname{Unif}(0,1)$. The MTE is defined as the partial derivative of the potential outcome with respect to the probability of being treated, conditional in a fixed value of the observed set and $U_{D}$ :

$$
M T E=\frac{\partial E(Y \mid X=x, P=p)}{\partial p}
$$

Intuitively, in equation (7), the MTE measures change in the production due to marginal increments in the probability of receiving technical assistance. Under this definition, equations (2-4), and the assumptions of the model, the following equation (8) represents the MTE:

$$
M T E=\alpha_{1}-\alpha_{0}+x\left(\beta_{1}-\beta_{0}\right)+\left(\rho_{1}-\rho_{0}\right) \Phi^{-1}\left(u_{D}\right)
$$

Parameters $\rho_{1}$ and $\rho_{0}$ represent the covariance between the unobservables of selection equation with unobservables of outcome equations for the treated and untreated units, respectively. We get $\alpha_{1}, \alpha_{0}, \beta_{1}, \beta_{0}, \rho_{1}, \rho_{0}$ by estimating the system of equations (2-4) by maximum likelihood (Brave and Walstrum, 2014). As demonstrated by Heckman and Vytlacil (2005), the treatment effects ATE, ATT, and ATUT are weighted averages of the MTE over the distribution of $U_{D}$; therefore, their estimation is resumed in equation (9):

$$
\Delta^{T E}(x)=\int_{0}^{1} \operatorname{MTE}\left(x, u_{D}\right) h_{T E}\left(x, u_{D}\right) d u_{D}
$$

where $h_{T E}\left(x, u_{D}\right)$ is the weight for each treatment effect. When ATT $>$ ATE $>$ ATUT, the treated units invest in technical assistance because they know that they will benefit more from it.

The MTE estimation also allows simulating the returns of policies for the marginal individual, the one indifferent between enrolling or not into a specific treatment. The Marginal Policy Relevant Treatment Effect (MPRTE) measures the average return of a policy for those induced to enroll into the treatment by increasing in the margin the probability of enrollment (equation 9 for a different set of weights) (Heckman and Vytlacil, 2001). This parameter sheds light on the returns of programs' expansion and compares what type of expansion generates more returns: a homogeneous increase in the program or one that favors the more prone to enroll.

\subsection{Instrumental Variables}

This analysis uses exposure to conflict and planting cost as instrumental variables. Colombia has a long history of armed conflict in which Marxist guerrillas have been fighting the government in an attempt to gain political power. Therefore, the CNA includes a question about exposure to armed conflict in the household characteristics section. ${ }^{4}$ For this study, we created a measure of exposure to conflict at agricultural unit level. This variable shows the percentage of households affected by armed conflict within the agricultural unit before 2013. We used data on forced displacement, land dispossession, and land abandonment reported by every household within each agricultural unit to calculate this variable.

Armed conflict in Colombia takes place in rural areas. In response to this situation, the technical assistance national public program-AIS - included a project designed for producers in vulnerable conditions such as armed conflict. Asistencia Técnica Especial provided comprehensive support and knowledge transfer to small agricultural units. Given that one of the most frequent forms of victimization in rural areas is forced displacement, this involuntary movement of people

${ }^{4}$ Question 179 (DANE, 2014b). 
is an important determinant of the probability to receive technical assistance. Projects focusing on rural households exposed to conflict are likely to improve their production techniques, but the fact that a household is exposed to armed conflict is an exogenous shock, unlikely to be desired or anticipated by the household. Therefore, exposure to conflict is plausibly independent of the agricultural unit unobserved characteristics. The only way that exposure to the conflict could affect production is through inducing agricultural units to get technical assistance based on the targeting mechanisms of the project Asistencia Técnica Especial. Table 3 (First stage) illustrates the statistically significant relationship between forced displacement and the propensity of technical assistance.

The other instrument captures one of the most critical market costs that agricultural producers face, planting cost. Technical assistance provides technology that can reduce production costs, so agricultural units facing higher planting costs may be induced to join technical assistance programs. However, agricultural units cannot affect the market planting cost because it is a market result subject to the evolution of input prices and agricultural services. In addition, the agricultural sector is highly competitive and we enhanced the exogeneity of this IV by using the costs in other markets for the same crop. To compute the planting cost in unit $i$, we used the same crop average cost in all other states. Finally, when we estimated IV regressions with exposure to conflict and planting cost IV separately, the local effects' magnitudes are similar. Table 3 (First stage) shows a positive and statistically significant correlation between planting cost and technical assistance propensity.

Based on our first stage results, the instruments used for this estimation are relevant to explain the decision to participate in a technical assistance program. The first-stage F-statistic, proposed by Montiel Olea and Pflueger (2013), rejects the null hypothesis of weak instruments. Table 3 also reports results of the selection equation estimation (equation 4). This regression captures the relation between technical assistance and our instruments using a probit model. The estimation of equation (4) is equivalent to the first stage of a two-stage least squares model. Our instruments are statistically significant in all specifications, and the $t$-statistics are sizeable. Results from the selection equation display a positive relationship between planting cost and the probability of adopting technical assistance, and a positive association between exposure to conflict and the probability of adopting technical assistance.

\section{Results}

To estimate the effect of technical assistance on agricultural production value, we estimated the MTE, ATE, ATT, and the ATUT. We also estimated the MPRTE; a policy simulation that measures the effect of increasing the probability of treatment. Finally, for the sake of comparison, we estimated ordinary least squares (OLS), instrumental variables (IV) and two-stage least squares (2SLS) models as well. The 2SLS estimation is also useful for testing our instruments' validity.

\subsection{OLS, IV, and 2SLS Estimations}

Table 4 shows estimations for OLS, IV, and 2SLS using fixed effects and Eicker-Huber-White standard errors clustered by vereda. Column (1) reports results for the OLS estimation. Columns (2) and (3) present IV results for the following instrumental variables: exposition to conflict and planting cost. Column (4) shows 2SLS results using both instruments together. We also performed a standard over-identification restriction test (Hassen J) in the regression with both instruments. ${ }^{5}$ Under the null hypothesis, instruments are valid because they are uncorrelated

\footnotetext{
${ }^{5} \mathrm{We}$ argue that the variations in planting cost would induce units to enroll in technical assistance projects because when this cost is high, units get more benefits from consulting and assistance services. Nevertheless, since our dependent variable is the value of the production by hectare (not profits), we consider that it is very plausible that the instrument only influences the dependent variable by its effect on the treatment variable. Our over-identification restriction tests support this assumption.
} 
Table 3. First stage and selection equation

\begin{tabular}{|c|c|c|c|c|c|c|}
\hline & \multicolumn{3}{|c|}{ First stage (OLS) } & \multicolumn{3}{|c|}{ Selection equation (Probit) } \\
\hline & 1 & 2 & 3 & 4 & 5 & 6 \\
\hline \multicolumn{7}{|l|}{ Instruments } \\
\hline \multirow[t]{2}{*}{ Exposure to conflict } & $0.018^{\star \star \star}$ & & $0.018^{\star \star \star}$ & $0.019^{\star \star \star}$ & & $0.019^{\star \star *}$ \\
\hline & $(0.004)$ & & $(0.004)$ & $(0.004)$ & & $(0.004)$ \\
\hline \multirow[t]{2}{*}{ Planting cost } & & $0.034^{\star \star \star}$ & $0.034^{\star \star \star}$ & & $0.038^{\star \star \star}$ & $0.038^{\star \star *}$ \\
\hline & & $(0.001)$ & $(0.001)$ & & $(0.001)$ & $(0.001)$ \\
\hline \multicolumn{7}{|l|}{ Controls } \\
\hline \multirow[t]{2}{*}{ Size agricultural unit } & $0.054^{\star \star \star}$ & $0.032^{\star \star \star}$ & $0.032^{\star \star \star}$ & $0.050^{\star \star \star}$ & $0.025^{\star \star \star}$ & $0.025^{\star \star \star}$ \\
\hline & $(0.001)$ & $(0.001)$ & $(0.001)$ & $(0.001)$ & $(0.002)$ & $(0.001)$ \\
\hline \multirow[t]{2}{*}{ Permanent job } & $0.001^{\star \star \star}$ & $0.001^{\star \star \star}$ & $0.001^{\star \star \star}$ & $0.001^{\star \star \star}$ & $0.002^{\star \star \star}$ & $0.002^{\star \star \star}$ \\
\hline & $(0.000)$ & $(0.000)$ & $(0.000)$ & $(0.000)$ & $(0.000)$ & $(0.000)$ \\
\hline \multirow[t]{2}{*}{ Machinery ownership } & $0.048^{\star \star \star}$ & $0.050^{\star \star \star}$ & $0.050^{\star \star \star}$ & $0.065^{\star \star \star}$ & $0.064^{\star \star \star}$ & $0.064^{\star \star *}$ \\
\hline & $(0.003)$ & $(0.003)$ & $(0.003)$ & $(0.003)$ & $(0.003)$ & $(0.003)$ \\
\hline \multirow[t]{2}{*}{ Area agricultural infrastructure } & $0.011^{\star \star \star}$ & $0.010^{\star \star \star}$ & $0.010^{\star \star \star}$ & $0.015^{\star \star \star}$ & $0.014^{\star \star \star}$ & $0.014^{\star \star *}$ \\
\hline & $(0.001)$ & $(0.001)$ & $(0.001)$ & $(0.001)$ & $(0.001)$ & $(0.001)$ \\
\hline \multirow[t]{2}{*}{ Percentage men in households } & $-0.010^{\star *}$ & $-0.009^{\star \star}$ & $-0.009^{\star \star}$ & $-0.011^{\star \star}$ & $-0.008^{\star}$ & $-0.008^{\star}$ \\
\hline & $(0.004)$ & $(0.004)$ & $(0.004)$ & $(0.005)$ & $(0.004)$ & $(0.004)$ \\
\hline \multirow[t]{2}{*}{ Average household size } & $0.001^{\star \star \star}$ & $0.002^{\star \star \star}$ & $0.002^{\star \star \star}$ & $0.001^{*}$ & $0.001^{\star \star \star}$ & $0.001^{\star \star *}$ \\
\hline & $(0.000)$ & $(0.000)$ & $(0.000)$ & $(0.000)$ & $(0.000)$ & $(0.000)$ \\
\hline \multirow[t]{2}{*}{ Average education in household } & $0.006^{\star \star \star}$ & $0.006^{\star \star \star}$ & $0.006^{\star \star \star}$ & $0.007^{\star \star \star}$ & $0.007^{\star \star \star}$ & $0.007^{\star \star \star}$ \\
\hline & $(0.001)$ & $(0.001)$ & $(0.001)$ & $(0.001)$ & $(0.001)$ & $(0.001)$ \\
\hline \multirow[t]{2}{*}{ Average age in household } & $-0.000^{*}$ & $-0.000^{\star}$ & -0.000 & -0.000 & -0.000 & -0.000 \\
\hline & $(0.000)$ & $(0.000)$ & $(0.000)$ & $(0.000)$ & $(0.000)$ & $(0.000)$ \\
\hline \multirow[t]{2}{*}{ Percentage people older 10} & -0.005 & -0.004 & -0.004 & $-0.016^{*}$ & $-0.017^{\star \star}$ & $-0.017^{\star \star}$ \\
\hline & $(0.008)$ & $(0.008)$ & $(0.007)$ & $(0.008)$ & $(0.008)$ & $(0.008)$ \\
\hline \multirow[t]{2}{*}{ Percentage men head of household } & $0.018^{\star \star \star}$ & $0.019^{\star \star \star}$ & $0.019^{\star \star \star}$ & $0.017^{\star \star \star}$ & $0.017^{\star \star \star}$ & $0.017^{\star \star \star}$ \\
\hline & $(0.003)$ & $(0.003)$ & $(0.003)$ & $(0.003)$ & $(0.003)$ & $(0.003)$ \\
\hline \multirow[t]{2}{*}{ Average education head of household } & $0.001^{\star \star}$ & $0.001^{\star \star \star}$ & $0.001^{\star \star \star}$ & 0.001 & $0.001^{*}$ & $0.001^{*}$ \\
\hline & $(0.000)$ & $(0.000)$ & $(0.000)$ & $(0.001)$ & $(0.001)$ & $(0.001)$ \\
\hline \multirow[t]{2}{*}{ Average age head of household } & $0.000^{\star \star}$ & $0.000^{\star \star \star}$ & $0.000^{\star \star \star}$ & 0.000 & $0.000^{\star \star}$ & $0.000^{\star *}$ \\
\hline & $(0.000)$ & $(0.000)$ & $(0.000)$ & $(0.000)$ & $(0.000)$ & $(0.000)$ \\
\hline Joint $F$ & 25.913 & 785.906 & 403.426 & & & \\
\hline Vereda fixed effects & Yes & Yes & Yes & No & No & No \\
\hline Mean variables at vereda level & No & No & No & Yes & Yes & Yes \\
\hline Clusters & 14,748 & 14,637 & 14,637 & 14,748 & 14637 & 14637 \\
\hline Observations & 191,588 & 188,706 & 188,706 & 191,588 & 188,706 & 188,706 \\
\hline
\end{tabular}

Notes: Standard errors clustered by vereda level. Dependent variable is a dummy for receiving technical assistance. For a threshold tau $=10 \%$, all instruments reject the null hypothesis of weak instrument. ${ }^{* \star *} \mathrm{p}<0.01,{ }^{\star \star} \mathrm{p}<0.05,{ }^{*} \mathrm{p}<0.10$ 
Table 4. OLS, IV, and 2SLS regressions

\begin{tabular}{|c|c|c|c|c|}
\hline & $\begin{array}{c}\text { OLS } \\
1\end{array}$ & $\begin{array}{c}\text { Exposure to conflict } \\
2\end{array}$ & $\begin{array}{c}\text { Planting cost } \\
3\end{array}$ & $\begin{array}{c}\text { Both instruments } \\
4\end{array}$ \\
\hline \multirow[t]{2}{*}{ Technical assistance } & $-0.042^{\star \star \star}$ & $0.488^{\star}$ & $0.561^{\star \star \star}$ & $0.561^{\star \star \star}$ \\
\hline & $(0.004)$ & $(0.257)$ & $(0.053)$ & $(0.052)$ \\
\hline \multicolumn{5}{|l|}{ Controls } \\
\hline \multirow[t]{2}{*}{ Size agricultural unit } & $-0.006^{\star \star \star}$ & $-0.034^{\star \star}$ & $-0.039^{\star \star \star}$ & $-0.039^{\star \star *}$ \\
\hline & $(0.001)$ & $(0.014)$ & $(0.003)$ & $(0.003)$ \\
\hline \multirow[t]{2}{*}{ Permanent job } & 0.000 & -0.000 & -0.000 & -0.000 \\
\hline & $(0.000)$ & $(0.000)$ & $(0.000)$ & $(0.000)$ \\
\hline \multirow[t]{2}{*}{ Machinery ownership } & $0.020^{\star \star \star}$ & -0.006 & $-0.009^{\star \star}$ & $-0.009^{\star \star}$ \\
\hline & $(0.004)$ & $(0.013)$ & $(0.005)$ & $(0.005)$ \\
\hline \multirow[t]{2}{*}{ Area agricultural infrastructure } & $0.002^{\star \star \star}$ & -0.003 & $-0.004^{\star \star \star}$ & $-0.004^{\star \star \star}$ \\
\hline & $(0.001)$ & $(0.003)$ & $(0.001)$ & $(0.001)$ \\
\hline \multirow[t]{2}{*}{ Percentage men in households } & $0.014^{\star \star \star}$ & $0.020^{\star \star \star}$ & $0.021^{\star \star \star}$ & $0.021^{\star \star \star}$ \\
\hline & $(0.005)$ & $(0.006)$ & $(0.006)$ & $(0.006)$ \\
\hline \multirow[t]{2}{*}{ Average household size } & $-0.001^{\star}$ & $-0.001^{\star \star}$ & $-0.001^{\star \star \star}$ & $-0.001^{\star \star \star}$ \\
\hline & $(0.000)$ & $(0.001)$ & $(0.000)$ & $(0.000)$ \\
\hline \multirow[t]{2}{*}{ Average education in household } & $0.003^{\star \star \star}$ & -0.000 & -0.001 & -0.001 \\
\hline & $(0.001)$ & $(0.002)$ & $(0.001)$ & $(0.001)$ \\
\hline \multirow[t]{2}{*}{ Average age in household } & 0.000 & 0.000 & 0.000 & 0.000 \\
\hline & $(0.000)$ & $(0.000)$ & $(0.000)$ & $(0.000)$ \\
\hline \multirow{2}{*}{ Percentage people older 10} & $-0.024^{\star \star}$ & $-0.021^{\star \star}$ & $-0.022^{\star \star}$ & $-0.022^{\star \star}$ \\
\hline & $(0.010)$ & $(0.011)$ & $(0.011)$ & $(0.011)$ \\
\hline \multirow[t]{2}{*}{ Percentage men head of household } & 0.002 & -0.007 & $-0.012^{\star \star \star}$ & $-0.012^{\star \star \star}$ \\
\hline & $(0.003)$ & $(0.006)$ & $(0.004)$ & $(0.004)$ \\
\hline \multirow[t]{2}{*}{ Average education head of household } & 0.000 & -0.001 & -0.000 & -0.000 \\
\hline & $(0.001)$ & $(0.001)$ & $(0.001)$ & $(0.001)$ \\
\hline \multirow[t]{2}{*}{ Average age head of household } & $-0.000^{\star \star \star}$ & $-0.001^{\star \star \star}$ & $-0.001^{\star \star \star}$ & $-0.001^{\star \star \star}$ \\
\hline & $(0.000)$ & $(0.000)$ & $(0.000)$ & $(0.000)$ \\
\hline Hansen J Statistic $P$ value & & & & 0.995 \\
\hline Vereda fixed effects & Yes & Yes & Yes & Yes \\
\hline Clusters & 14,748 & 14,748 & 14,637 & 14,637 \\
\hline Observations & 191,588 & 191,588 & 188,706 & 188,706 \\
\hline
\end{tabular}

Notes: Standard errors clustered by vereda level. ${ }^{*} p<0.1,{ }^{\star \star \star} p<0.01$.

with the error term. Based on our results, we do not reject the hypothesis that all IVs are valid, given its uncorrelation with the structural equation's regression error. Therefore, we argue that exposure to conflict and planting cost are independent of the agricultural unit's unobserved characteristics. 
Columns (2) and (3) show results for models exactly identified for each IV separately. Using exposure to conflict (column 2), the effect of technical assistance for those induced to participate in the program as a result of being exposed to armed conflict is $48 \%$. Using planting cost (column 3 ), the effect is $56 \%$. Both of these results are statistically significant, so agricultural units induced to participate in technical assistance programs increase their production value per hectare between 48 and 56\%. These findings are consistent with previous studies in Argentina reporting yield increments between 46 and 58\% after joining technical assistance programs (Cerdán-Infantes et al., 2008), and results from a meta-analysis of 292 publications reporting median rates of return to extension efforts of 58\% (Alston et al., 2000). However, in Colombia, they are particularly relevant because improvement of living conditions in rural areas is a priority, and technical assistance provides a mechanism to increase agricultural productivity, thus rural population income.

Results from the 2SLS estimation in column (4) also show a positive local effect of technical assistance on agricultural production value. Using both instruments, joining a technical assistance program increases production value per hectare by $56 \%$. Coefficients on some control variables are also statistically significant. However, they should be interpreted with caution because in this analysis we control for endogeneity only in our main independent variable-technical assistance. There is a negative relationship between average age of the head of household and agricultural production value per hectare. Previous studies suggested that this relationship is mediated by the risk of aversion (Picazo-Tadeo and Wall, 2011). Hence, the older the head of household, the less likely he or she is to adopt new technologies (Dercon and Christiaensen, 2011). This negative relationship implies that technical assistance programs should factor the age of the head of household in their design to improve results.

There are other interesting correlations between some covariates and the dependent variable. The size of the agricultural unit has a negative correlation with the agricultural production value per hectare. The direction of this result is expected because the dependent variable is the value of the production per hectare. The size of the household has a negative correlation with the dependent variable as well. This result could be capturing the negative relationship between fertility/ family size and income (Ashraf et al., 2013; Schultz, 1997). There is also a negative correlation between the percentage men head of household and agricultural production value. Nevertheless, there is a positive correlation of the dependent variable with the percentage of men in the household. These results bring in the discussion about gender differences in agricultural productivity (Peterman et al., 2011; Quisumbing, 1996; Slavchevska, 2015; Udry, 1996), a very relevant and interesting topic that remains material for future research.

\subsection{MTE Estimation}

Our main model is a parametric estimation of the equation system (2), (3), and (4), which in turn allows the estimation of our main evaluation parameter: the MTE (see equation 8). The MTE describes the heterogeneity in the return of technical assistance on agricultural production value per hectare. Table 5, column (1), presents the result of a test of heterogeneity in the returns. We test if the slope of the MTE is statistically equal to zero, $\left(\rho_{1}-\rho_{0}\right)=0$. Based on our results, we reject the hypothesis at the $95 \%$ confidence level. Therefore, there is heterogeneity in the returns of technical assistance on agricultural production value per hectare.

Figure 1 illustrates the MTE estimation and shows a sizable heterogeneity of returns. The horizontal axis in Figure 1 is a function of the probability of selection into treatment. Individuals with a high probability of selection have a higher return of enrolling into technical assistance programs. Individuals with a low probability of selection have lower returns. On the one hand, we find a positive return of $115 \%$ for producers that, given their unobservable characteristics, are the most likely to enroll in technical assistance programs (percentile 10 of the distribution of $u_{D}$ in equation 7). On the other hand, we find a negative return of $15 \%$ for producers that given their unobservable characteristics, have the lowest probability to enroll in technical assistance programs 
Table 5. MTE estimation, treatment effects, and policy estimates

\begin{tabular}{|c|c|c|c|c|c|}
\hline \multicolumn{2}{|c|}{ MTE slope } & \multicolumn{2}{|c|}{ Treatment effects } & \multicolumn{2}{|c|}{ MPRTE } \\
\hline 1 & & \multicolumn{2}{|c|}{2} & \multicolumn{2}{|c|}{3} \\
\hline \multirow[t]{2}{*}{$\rho_{1}$} & $-0.609^{\star \star \star}$ & ATE & $0.504^{\star \star \star}$ & $P+\alpha$ & $0.638^{\star \star \star}$ \\
\hline & $(0.0177)$ & & $(0.011)$ & & $(0.013)$ \\
\hline \multirow[t]{2}{*}{$\rho_{0}$} & $0.0987^{\star \star \star}$ & ATT & $0.924^{\star \star \star}$ & $P(1+\alpha)$ & $0.506^{\star \star \star}$ \\
\hline & $(0.0161)$ & & $(0.020)$ & & $(0.012)$ \\
\hline \multirow[t]{2}{*}{$\rho_{1}-\rho_{0}$} & $-0.510^{\star \star \star}$ & ATUT & $0.212^{\star \star \star *}$ & & \\
\hline & $(0.0258)$ & & $(0.012)$ & & \\
\hline
\end{tabular}

Notes: Standard errors are calculated with bootstrap (100 repetitions). Control variables not reported in this table, but included in estimations, are agricultural production unit characteristics and characteristics of households within the agricultural unit. ${ }^{\star \star \star} p<0.01$

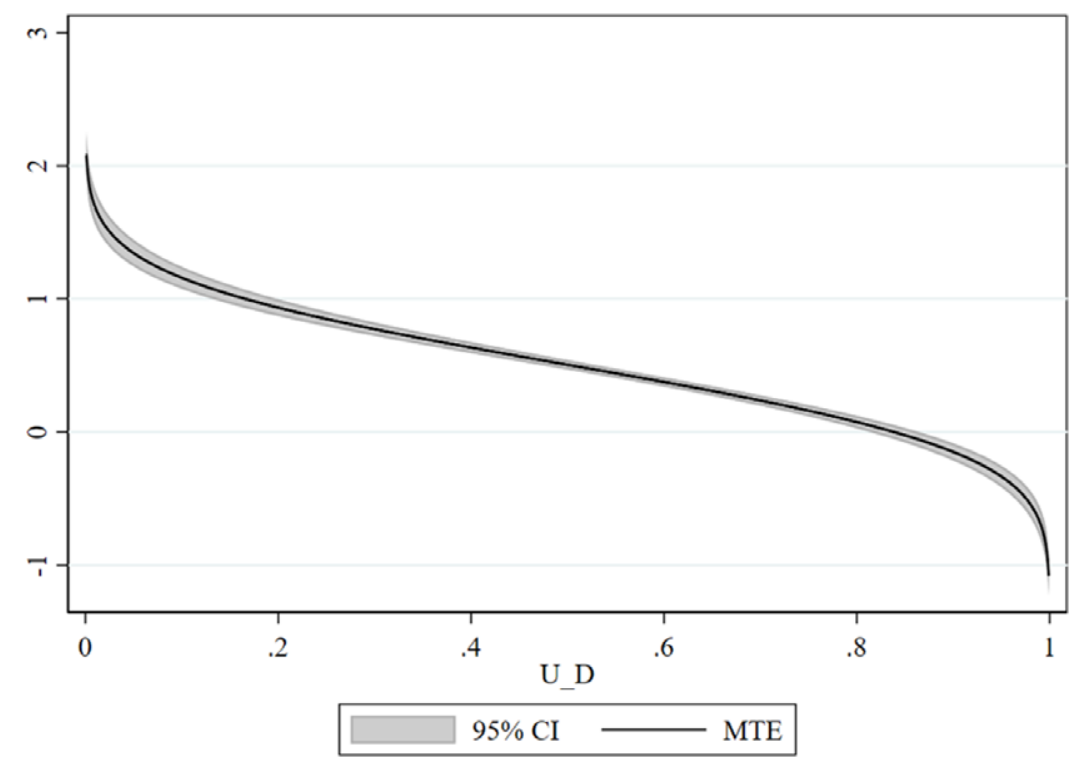

Figure 1. MTE estimated.

Notes: The MTE is calculated in the average of the observed characteristics. Confidence bands are calculated using delta method and standard errors clustered by vereda level. The vertical axis shows the effect of technical assistance for each evaluation point of $U_{D}$ between [0.01,0.99] in steps of 0.01 (Brave and Walstrum, 2014).

(percentile 90 of the distribution of $u_{D}$ ). This pattern of selection on expected gains has been previously studied (Heckman and Vytlacil, 2005) and explains the positive sorting gains observed in our results.

Column (2) reports results for standard treatment effects. The ATE of enrolling in a technical assistance program is an increase of $50.4 \%$ of agricultural production value per hectare, relative to the situation without technical assistance. This result is consistent with rates of return to technical assistance, greater than or equal to 50\%, found in previous studies in other 17 countries (Evenson, 1997). Specifically for Latin America, rates of return to technical assistance could reach up to $80 \%$ (Evenson, 2001). In the same column, the ATT and ATUT point out a positive sorting on gains in technical assistance adoption by agricultural producers. Agricultural units enrolled in technical assistance programs have greater returns to technical assistance, in terms of agricultural production value per hectare (92.4), than those who did not enroll (21.2), in the counterfactual scenario 
in which they would have enrolled. Therefore, it is likely that beneficiaries of technical assistance services enrolled in the programs because they had the expectation that their productivity would increase.

Using the results from the ATE estimation, we also compute a back to the envelope calculation of the average cost-benefit ratio of providing technical assistance. This is an approximation because we have aggregated information on cost and potential beneficiaries. Using aggregated information on the total technical assistance investment, potential beneficiaries, and our estimation of technical assistance enrollment rate, we find that the average amount of subsidies provided by the Colombian government, in 2013 to get technical assistance, was around 257 USD. ${ }^{6}$ The average agricultural production value per hectare in our sample is 1467 USD, so an ATE of 50.4 percentage implies an average increase of 778 USD. Therefore, the cost-benefit ratio is 3 , (778 /257); for every 1 USD spent on technical assistance, the producer receives an increase in agricultural production of 3 USD. Based on our results, technical assistance is a cost-effective strategy to boost agricultural productivity.

To verify the validity of the instruments and the fact that specific subpopulations do not drive our results, we perform some robustness exercises. Regarding the validity of the instruments, we use the median and weighted average planting cost for the same crop in other states. Our results are robust to these changes, and in all over-identified regressions, the instruments are valid in terms of the identifying restriction test (Hansen J Statistic) (Results available in Appendix 3). Because the National Federation of Coffee Growers has an extensive technical assistance program and reaches most coffee producers in Colombia, we test if coffee producers are driving our results. To do so, we exclude them from the sample and re-estimate previous exercises. We find that technical assistance has a positive effect on agricultural production value per hectare in places where coffee is not the main crop. The estimated coefficients are larger than the ones obtained for the whole sample (Results available in Appendix 4). Therefore, our main result holds for a sample of producers who are not coffee growers. There are positive effects of technical assistance in sectors different to coffee, and our findings are robust to changes in the set of instruments.

\subsection{Technical Assistance Policies Simulations}

In addition to traditional impact evaluation parameters, ATE, ATT, and ATUT, the MTE estimation allows the simulation of policy responses for the marginal individual. The Marginal Policy Relevant Treatment Effect (MPRTE) measures the effect of increasing marginally the probability of treatment (Carneiro et al., 2011; Heckman and Vytlacil, 2005), for instance, the impact of a small increase in the probability of enrolling in technical assistance on agricultural production value per hectare. Based on our results, technical assistance has a positive impact on agricultural production value. Hence, we estimate the effect of two different policies: one policy that homogeneously expands technical assistance program coverage and another that proportionally increases the probability of enrolling in technical assistance programs. The first policy increases the probability of obtaining technical assistance equally among producers, while the second policy favors producers who are more likely to receive technical assistance. Linking these policies to the selection model presented in equation (4), we can express them as changes in the propensity score, $P+\alpha$ and $P(1+\alpha)$, respectively.

Table 5, column (3), presents the MPRTE estimates for technical assistance policies. First, we estimate the effect of increasing homogeneously the probability of receiving technical assistance, $P+\alpha$. We find that increasing one percentage point the probability of enrollment into technical assistance increases agricultural production value per hectare by $63.8 \%$ for the marginal individual. Then, we estimate the effect of increasing proportionally the probability of receiving technical

\footnotetext{
${ }^{6}$ The average subsidy is estimated using administrative records of the Ministry of Agriculture available at: https://www. minagricultura.gov.co/Documents/Informe_2013_2014_Final.pdf.
} 
Table 6. Heterogeneous effect by agricultural unit size

\begin{tabular}{|c|c|c|c|c|}
\hline & Less than 1.3 ha & 1.3 ha to 3.9 ha & 3.9 ha to 11 ha & More than 11 ha \\
\hline \multirow[t]{2}{*}{ ATE } & $0.5204^{\star \star *}$ & $0.3587^{\star \star \star}$ & $0.396^{\star \star \star}$ & $0.7235^{\star \star \star}$ \\
\hline & $(0.0542)$ & $(0.0238)$ & $(0.0171)$ & $(0.198)$ \\
\hline \multirow[t]{2}{*}{ ATT } & $0.6748^{\star \star \star}$ & $0.6054^{\star \star \star}$ & $0.777^{\star \star \star}$ & $1.3192^{\star \star \star}$ \\
\hline & $(0.1063)$ & $(0.0276)$ & $(0.0259)$ & $(0.3669)$ \\
\hline \multirow[t]{2}{*}{ ATUT } & $0.4537^{\star \star \star}$ & $0.0951^{\star *}$ & $0.0316^{\star}$ & $0.3619^{\star \star *}$ \\
\hline & $(0.0568)$ & $(0.0409)$ & $(0.0197)$ & $(0.0957)$ \\
\hline \multirow[t]{2}{*}{ MPRTE: $P+\alpha$} & $0.6143^{\star \star \star}$ & $0.3434^{\star \star \star}$ & $0.4164^{\star \star \star}$ & $0.9634^{\star \star \star}$ \\
\hline & $(0.0815)$ & $(0.025)$ & $(0.0187)$ & $(0.2659)$ \\
\hline \multirow[t]{2}{*}{ MPRTE: $P(1+\alpha)$} & $0.5595^{\star \star \star}$ & $0.2424^{\star \star \star}$ & $0.2711^{\star \star \star}$ & $0.7911^{\star \star \star}$ \\
\hline & $(0.0625)$ & $(0.0304)$ & $(0.0192)$ & $(0.2163)$ \\
\hline Observations & 48,752 & 48,752 & 48,752 & 48,752 \\
\hline Assisted units (\%) & 30.06 & 52.37 & 49.58 & 38.31 \\
\hline
\end{tabular}

Notes: Ha refers to hectares. Standard errors calculated with bootstrap (100 repetitions). Control variables not reported in this table, but included in estimations, are agricultural production unit characteristics and households within the unit. ${ }^{\star \star \star} p<0.01,{ }^{* \star} p<0.05,{ }^{*} p<0.1$

assistance, $P(1+\alpha)$. In this case, we find that if the probability of enrollment increases $1 \%$, agricultural production value increases by $50.6 \%$ for the marginal individual. Therefore, a policy that uniformly increases the coverage of technical assistance is more effective than one that increases coverage to producers who, in the baseline, had more chances of receiving technical assistance.

\subsection{Heterogeneity by Agricultural Unit Size}

Previous estimations assume that technology of production is homogenous among producers. However, this assumption might be restrictive and can hide differences in technical assistance performance across agricultural production units. Therefore, we re-estimate the model, dividing our sample by quartiles of land size. Table 6 presents the treatment effects and policy parameters by samples according to the agricultural unit size. The ATE exhibits $U$ shape results depending on agricultural unit size. On average, the smallest and largest units would benefit the most from joining technical assistance programs. These results are relevant for public policy strategies focusing on higher returns of investment.

Agricultural units with more than 11 hectares have the highest ATT effect, and in all cases, the ATT is higher than the ATUT. These results support the existence of selection on expected gains. This type of sorting pattern is more important for larger agricultural units because they are probably the most productive ones. Another interesting finding is that the ATUT is the highest for the smallest units. Therefore, in the counterfactual scenario in which non-treated small units would have received technical assistance, they would have increased their production value by $45 \%$. This result contributes to the discussion of the role of scaling technical assistance programs. There are concerns in the literature about whether those who are getting assistance are the ones who would benefit most from it (Anderson and Feder, 2007; Hellin, 2012). Our estimation results show that agricultural policies should target technical assistance programs on the smallest units, for which there are ample opportunities for the marginal benefits. 


\section{Conclusions}

In this paper, we find that technical assistance has the potential to increase agricultural production. Technical assistance has a large and positive average effect on the value of production per hectare, $50.4 \%$. This result is consistent with the average return of technical assistance investments found in many developing countries (Anderson and Feder, 2007; Evenson, 1997). One of our main findings is that this effect is not homogeneous through all units. We find that the marginal effect for agricultural units with a higher probability of being treated could reach 115\%; nevertheless, the effect could be negative for those with the smallest probability of treatment. In line with this evidence, the ATT (92\%) is far greater than the ATUT (21\%), revealing the existence of sorting on gains. Agricultural units that are induced to the treatment are the ones with higher expectations of the effect of technical assistance in their production.

This paper also explores the effect of technical assistance programs for victims of armed conflict. In the literature, there is no evidence on the positive impact of policies directed to rural populations affected by armed conflict; nevertheless, there is evidence of the negative effect of conflict on food security in developing countries (Jeanty and Hitzhusen, 2006). In a similar study, Segovia (2017) finds negative effects of armed conflict on Colombia's food security. In terms of policy implications, our findings stress the benefit of maintaining and expanding technical assistance programs and the need to implement policies targeting armed conflict zones. Our results provide evidence that policies directed to farms affected by violence are an effective strategy to increase agricultural productivity, increase income, and help victims overcome poverty. Finally, our findings reveal that there is still a considerable margin for technical assistance program extensions since the ATUT is still a considerable $21 \%$.

Acknowledgments. We would like to thank Camilo Bohorquez-Penuela for his helpful feedback on multiple drafts of this paper. We are also grateful to the editor and three anonymous reviewers for their constructive comments and suggestions. Thank you as well to Johanna Yepes for her support to advance this research project. All remaining errors are our own.

Competing Interests. Nicolás Arturo Torres Franco has received a scholarship from Universidad EAFIT. Eleonora Dávalos and Leonardo Fabio Morales declare none.

Data Availability Statement. The data that support the findings of this study are openly available in https:/github.com/ eleodavalos/heterogeneousTA.

Funding Statement. This research received no specific grant from any funding agency, commercial or not-for-profit sectors.

\section{References}

Agronet. Costos de Producción Agrícola, 2010.

Aker, J.C. "Dial "A" for Agriculture: A Review of Information and Communication Technologies for Agricultural Extension in Developing Countries." Agricultural Economics 42(2011):631-47. doi: 10.1111/j.1574-0862.2011.00545.x.

Alston, J.M., C. Chan-Kang, M.C. Marra, P.G. Pardey, and T.J. Wyatt (2000). A Meta-Analysis of Rates of Return to Agricultural $R$ \& D: ExPede Herculem? Retrieved from http://ebrary.ifpri.org/utils/getfile/collection/p15738coll2/id/ 125334/filename/125335.pdf

Anderson, J.R., and G. Feder. “Chapter 44 Agricultural Extension.” Handbook of Agricultural Economics 3(2007):2343-78. doi: 10.1016/S1574-0072(06)03044-1.

Ashraf, Q.H., D.N. Weil, and J. Wilde. "The Effect of Fertility Reduction on Economic Growth." Population and Development Review 39,1(2013):97-130. http://ezproxy.eafit.edu.co/login?url=; http://search.ebscohost.com/login.aspx? direct $=$ true\&db=edsjsr\&AN=edsjsr.41811954\&lang=es\&site=eds-live\&scope $=$ site.

Bank, W. World Development Indicators: Agriculture, forestry, and fishing value added per worker, 2021. Retrieved from https://databank.worldbank.org/reports.aspx? source=2\&series=NV.AGR.EMPL.KD\&country=\#

Benyishay, A., and A.M. Mobarak. Social Learning and Incentives for Experimentation and Communication. The Review of Economics Studies rdy039(2018). doi: 10.1093/restud/rdy039/5061309.

Brave, S., and T. Walstrum. "Estimating Marginal Treatment Effect using Parametric and Semiparametric Methods." The Stata Journal 14,1(2014):191-217.

Bravo-Ureta, B.E., and R. Evenson. "Efficiency in Agricultural Production: The Case of Peasant Farmers in Eastern Paraguay.” Agricultural Economics 10,1(1994):27-37. doi: 10.1016/0169-5150(94)90037-X. 
Carneiro, P., J.J. Heckman, and E. Vytlacil. "Estimating Marginal Returns to Education.” American Economic Review 101,6(2011):2754-81. doi: 10.1257/aer.101.6.2754.

Carneiro, P., M. Lokshin, and N. Umapathi. “Average and Marginal Returns to Upper Secondary Schooling in Indonesia.” Journal of Applied Econometrics 32,1(2017):16-36. doi: 10.1002/jae.2523.

Cerdán-Infantes, P., A. Maffioli, and D. Ubfal (2008). The impact of agricultural extension services: The case of grape production in Argentina (No. OVE/WP-05/08). Washington, DC.

CNCA. Resolución No. 29 de 2008, (2008).

DANE. Censo Nacional Agropecuario 2014, (2014a).

DANE. Cuentas Nacionales de Colombia Base 2015, (2018). Retrieved from https://www.dane.gov.co/files/investigaciones/ boletines/pib/cuentas-nal-anuales/cuentas-nal-anuales-base-2015.pdf

DANE. Formulario de Unidades Productoras Agropecuarias y Predios con Actividad no Agropecuaria. Bogotá, DC, (2014b).

DANE. Glosario Tercer Censo Nacional Agropecuario. Bogota, DC, (2014c).

Dercon, S., and L. Christiaensen. "Consumption risk, Technology Adoption and Poverty Traps: Evidence from Ethiopia." Journal of Development Economics 96,2(2011):159-73. doi: 10.1016/j.jdeveco.2010.08.003.

Doss, C.R. "Analyzing Technology Adoption using Microstudies: Limitations, Challenges, and Opportunities for Improvement." Agricultural Economics 34(2006):207-19.

Egas Yerovi, J.J., and C.P. De Salvo. Agricultural Support Policies in Latin America, (2018). Retrieved from https://publications.iadb.org/publications/english/document/Agricultural-Support-Policies-in-Latin-America-and-theCaribbean-2018-Review.pdf

Evenson, R. "The Economic Contributions of Agricultural Extension to Agricultural an Rural Development." Improving Agricultural Extension. A Reference Manual. B. Swanson, R. Bentz, and A. Sofranko, eds. Rome: Food and Agriculture Organization of the United Nations, 1997.

Evenson, R. "Chapter 11 Economic Impacts of Agricultural Research and Extension." Handbook of Agricultural Economics 1(2001):573-628. doi: 10.1016/S1574-0072(01)10014-9.

Evenson, R., and D. Gollin. “Assessing the Impact of the Green Revolution, 1960 to 2000.” Science 300(2003):758-62. doi: 10. 1126/science.1078710.

FAO. The State of Food and Agriculture Innovation in Family Farming. Rome, 2014.

Feder, G., R. Murgai, and J. B. Quizon. "Sending farmers back to school: The impact of farmer field schools in Indonesia." Review of Agricultural Economics 26,1(2004):45-62. doi: 10.1111/j.1467-9353.2003.00161.x

Graeub, B.E., M.J. Chappell, H. Wittman, S. Ledermann, R.B. Kerr, and B. Gemmill-Herren. "The State of Family Farms in the World." World Development 87(2016):1-15. doi: 10.1016/j.worlddev.2015.05.012.

Gutierrez, L. "Why is Agricultural Labor Productivity Higher in Some Countries than Others?" Agricultural Economics Review 3,1(2002):58-72.

Heckman, J.J., S. Urzua, and E. Vytlacil. "Understanding Instrumental Variables in Models with Essential Heterogeneity." The Review of Economics and Statistics 88,3(2006):389-432. doi: 10.1162/rest.88.3.389.

Heckman, J.J., and E. Vytlacil. "Policy-Relevant Treatment Effects." The American Economic Review 91,2(2001):107-11.

Heckman, J.J., and E. Vytlacil. "Structural Equations, Treatment Effects, and Econometric Policy Evaluation 1." Econometrica 73,3(2005):669-738. doi: 10.1111/j.1468-0262.2005.00594.x.

Hellin, J. "Agricultural Extension, Collective Action and Innovation Systems: Lessons on Network Brokering from Peru and Mexico." Journal of Agricultural Education and Extension 18,2(2012):141-59. doi: 10.1080/1389224X.2012.655967.

ICA. Mis Buenas Prácticas Agrícolas. (2009). Retrieved from https://www.ica.gov.co/areas/agricola/servicios/inocuidadagricola/capacitacion/cartillabpa.aspx

Jeanty, P.W., and F. Hitzhusen. Analyzing the Effect of Conflict on Food Security in Developing Countries: An Instrumental Variable Panel Data Approach. Selected Paper Prepared for Presentation at the American Agricultural Economics Association (AAEA)'s Annual Meeting Held at Long Beach, California, July 23-26 2006, (2006).

Kassie, M., B. Shiferaw, and G. Muricho. "Agricultural Technology, Crop Income, and Poverty Alleviation in Uganda." World Development 39,10(2011):1784-95. doi: 10.1016/j.worlddev.2011.04.023.

Klerkx, L., F. Landini, and H. Santoyo-Cortés. "Agricultural extension in Latin America: current dynamics of pluralistic advisory systems in heterogeneous contexts." Journal of Agricultural Education and Extension 22, 5(2016):389-97. doi: 10.1080/1389224X.2016.1227044.

Kline, P., and C. Walters. "Evaluating Public Programs with Close Substitutes: The Case of Head Start." The Quarterly Journal of Economics 131,4(2016):1795-848.

Lambrecht, I., B. Vanlauwe, R. Merckx, and M. Maertens. "Understanding the Process of Agricultural Technology Adoption: Mineral Fertilizer in Eastern DR Congo.” World Development 59(2014):132-46. doi: 10.1016/j.worlddev. 2014.01.024.

Ley 1133 de 2007, (2007).

MADR. Informe de Rendición Pública de Cuentas Gestión 2013-2014. Bogotá, DC, 2014. 
Maestas, N., K.J. Mullen, and A. Strand. "Does Disability Insurance Receipt Discourage Work? Using Examiner Assignment to Estimate Causal Effects of SSDI Receipt.” American Economic Review 103,5(2013):1797-829. doi: 10.1257/aer.103.5. 1797.

Malikov, E., and S. C. Kumbhakar. "A generalized panel data switching regression model." Economics Letters 124,3(2014):353-357. doi: 10.1016/j.econlet.2014.06.022

Mendola, M. "Agricultural Technology Adoption and Poverty Reduction : A Propensity-score Matching Analysis for Rural Bangladesh.” Food Policy 32,3(2007):372-93. doi: 10.1016/j.foodpol.2006.07.003.

Montiel Olea, J.L., and C. Pflueger. “A Robust Test for Weak Instruments.” Journal of Business \& Economic Statistics 31,3(2013):358-69. doi: 10.1080/00401706.2013.806694.

Morales, L.F., C. Posso, and L.A. Flórez. Heterogeneity in the Returns to Tertiary Education for the Disadvantage Youth: Quality vs. Quantity Analysis. Borradores de Economía; No. 1150(2021).

Murgai, R. "The Green Revolution and the productivity paradox : evidence from the Indian Punjab.” Agricultural Economics 25(2001):199-209.

Noboa-Hidalgo, G.E., and S.S. Urzúa. "The Effects of Participation in Public Child Care Centers : Evidence from Chile." Journal of Human Capital 6,1(2012):1-34.

OECD/FAO. Latin American Agriculture: Prospects and challenges. In OECD-FAO Agricultural Outlook 2019-2028 (pp. 70 124). (2019). Retrieved from https://www.oecd-ilibrary.org/docserver/agr_outlook-2019-en.pdf?expires=1613148339\&id= id\&accname $=$ guest\&checksum $=55$ DB4C2E880A2794A295DBB2B68E34DA

OECD/UN/UNIDO. "What is in Colombia's Next Economic Chapter?" Production Transformation Policy Review of Colombia: Unleashing Productivity (pp. 43-79), (2019). Retrieved from https://www.oecd-ilibrary.org/docserver/ 9789264312289-en.pdf? expires $=1613055886 \& \mathrm{id}=\mathrm{id} \&$ accname $=$ guest $\&$ checksum $=$ B178D26A8BC05DAF48C04E62E4 9E408F

OECD. OECD Review of Agricultural Policies: Colombia 2015. OECD Publishing, 2015.

Peterman, A., A. Quisumbing, J. Behrman, and E. Nkonya. "Understanding the Complexities Surrounding Gender Differences in Agricultural Productivity in Nigeria and Uganda." Journal of Development Studies 47,10(2011):1482509. Retrieved from http://ezproxy.eafit.edu.co/login?url=; http://search.ebscohost.com/login.aspx?direct=true\&db= edb\&AN=66847308\&lang $=$ es\&site $=$ eds-live \&scope $=$ site.

Picazo-Tadeo, A.J., and A. Wall. "Production Risk, Risk Aversion and the Determination of Risk Attitudes among Spanish Rice Producers." Agricultural Economics 42,4(2011):451-64.

Quisumbing, A.R.. "Male-female Differences in Agricultural Productivity: Methodological Issues and Empirical Evidence." World Development 24,10(1996):1579. Retrieved from https:/librarylink.uncc.edu/login?url=; http://search.ebscohost. $\mathrm{com} /$ login.aspx?direct $=$ true $\& \mathrm{db}=\mathrm{bth} \& \mathrm{AN}=9702162034 \&$ site $=$ ehost-live $\&$ scope $=$ site.

Ragasa, C., and J. Mazunda. "The Impact of Agricultural Extension Services in the Context of a Heavily Subsidized Input System: The Case of Malawi.” World Development 105(2018):25-47. doi: 10.1016/j.worlddev.2017.12.004.

Rosegrant, M.W., and R. Evenson. "Agricultural Productivity Growth in Pakistan and India: A Comparative Analysis." Pakistan Development Review 32,4 Part I(1993):433-48. doi:10.30541/v32i4ipp.433-451.

Schultz, T.P.B. Chapter 8 Demand for children in low income countries. (1997). doi: 10.1016/S1574-003X(97)80025-6

Segovia, A.. "The Relationships between Food Security and Violent Conflicts: The Case of Colombia." FAO Agricultural Development Economics Working Paper. December, 2017.

Slavchevska, V.. "Gender Differences in Agricultural Productivity: The Case of Tanzania." Agricultural Economics 46,3(2015):335-55.

Udry, C. "Gender, Agricultural Production, and the Theory of the Household." The Journal of Political Economy 104,5(1996):1010-46. 


\section{Appendix 1. Percentage of agricultural units that received technical assistance by} topic

\begin{tabular}{|c|c|}
\hline Technical assistance topics & Percentage \\
\hline Good agricultural practices & 87.0 \\
\hline Good environmental practices & 12.6 \\
\hline Good farming practices & 11.4 \\
\hline Good practices in soil management & 12.4 \\
\hline Good post-harvesting practices & 5.6 \\
\hline Trace and commerce & 43.8 \\
\hline Associativity & 1.3 \\
\hline Financial education & 43.0 \\
\hline Entrepreneurship & 1.0 \\
\hline Traditional practices in agriculture & 1.7 \\
\hline
\end{tabular}

Notes: Percentage of agricultural units that reported technical assistance services by topic. Calculated based on DANE (2014a) data.

\section{Appendix 2. Descriptive statistics at crop level}

\begin{tabular}{|c|c|c|c|c|c|c|c|}
\hline Crop & $\begin{array}{l}\text { Mean } \\
\text { price } \\
\text { (COP per } \\
\text { kg) }\end{array}$ & $\begin{array}{l}\text { Total } \\
\text { states }\end{array}$ & $\begin{array}{c}\text { Percentage } \\
\text { area } \\
\text { planted }\end{array}$ & $\begin{array}{l}\text { Total agri- } \\
\text { cultural } \\
\text { units }\end{array}$ & $\begin{array}{c}\text { Percentage } \\
\text { agricultural } \\
\text { units with tech- } \\
\text { nical assistance }\end{array}$ & $\begin{array}{l}\text { Percentage agricul- } \\
\text { tural units without } \\
\text { technical assistance }\end{array}$ & $\begin{array}{l}\text { Difference in } \\
\text { average yield }\end{array}$ \\
\hline Plantain & 835 & 19 & 12.5381 & 298324 & 34.04 & 65.96 & $-0.07(24.46)^{\star \star \star}$ \\
\hline Coffee & 3731 & 23 & 11.1229 & 410053 & 61.57 & 38.43 & $-0.02(16.46)^{\star \star \star *}$ \\
\hline Paddy Rice & 858 & 10 & 7.0562 & 31221 & 23.74 & 76.26 & $0.36(51.3)^{\star \star \star}$ \\
\hline Cassava & 736 & 19 & 6.6202 & 178529 & 21.72 & 78.28 & $0.2(57.88)^{\star \star \star}$ \\
\hline Corn & 596 & 20 & 4.9195 & 107179 & 20.87 & 79.13 & $0.06(25.5)^{\star \star \star}$ \\
\hline Potato & 609 & 14 & 2.5383 & 34321 & 15.38 & 84.62 & $-0.16(21.73)^{\star \star \star}$ \\
\hline Banana & 657 & 15 & 2.1115 & 61752 & 27.8 & 72.2 & $0.26(28.83)^{\star \star \star}$ \\
\hline Pineapple & 998 & 19 & 1.4242 & 24808 & 22.87 & 77.13 & $0.01(1.19)$ \\
\hline Bean & 2964 & 20 & 1.2356 & 38670 & 30.18 & 69.82 & $0.08(5.96)^{\star * \star}$ \\
\hline Avocado & 2740 & 16 & 1.1183 & 30708 & 41.88 & 58.12 & $0.03(4.44)^{\star \star \star}$ \\
\hline Orange & 513 & 18 & 0.8287 & 24270 & 34.97 & 65.03 & $0.11(17.01)^{\star \star \star}$ \\
\hline $\begin{array}{l}\text { Sweet } \\
\text { potato }\end{array}$ & 1142 & 3 & 0.8182 & 17510 & 7.73 & 92.27 & $0.08(13.05)^{\star \star \star}$ \\
\hline Lemon & 1040 & 16 & 0.72 & 22124 & 25.7 & 74.3 & $0.08(11.92)^{\star \star \star}$ \\
\hline Coconut & 1767 & 12 & 0.6925 & 14326 & 15.01 & 84.99 & $-0.03(2.51)^{\star \star}$ \\
\hline
\end{tabular}


(Continued)

\begin{tabular}{|c|c|c|c|c|c|c|c|}
\hline Crop & $\begin{array}{l}\text { Mean } \\
\text { price } \\
\text { (COP per } \\
\text { kg) }\end{array}$ & $\begin{array}{l}\text { Total } \\
\text { states }\end{array}$ & $\begin{array}{c}\text { Percentage } \\
\text { area } \\
\text { planted }\end{array}$ & $\begin{array}{l}\text { Total agri- } \\
\text { cultural } \\
\text { units }\end{array}$ & $\begin{array}{c}\text { Percentage } \\
\text { agricultural } \\
\text { units with tech- } \\
\text { nical assistance }\end{array}$ & $\begin{array}{l}\text { Percentage agricul- } \\
\text { tural units without } \\
\text { technical assistance }\end{array}$ & $\begin{array}{l}\text { Difference in } \\
\text { average yield }\end{array}$ \\
\hline Blackberry & 2235 & 14 & 0.617 & 14550 & 28.8 & 71.2 & $0.02(2.59)^{\star \star \star}$ \\
\hline Tangerine & 1142 & 14 & 0.5649 & 14943 & 42.68 & 57.32 & $0.11(19.83)^{\star \star * *}$ \\
\hline Mango & 1444 & 18 & 0.4933 & 10083 & 26.82 & 73.18 & $0.04(2.95)^{\star \star \star}$ \\
\hline Guanabana & 2596 & 13 & 0.447 & 8133 & 33.32 & 66.68 & $0.01(0.33)$ \\
\hline Guava & 1320 & 18 & 0.438 & 10848 & 34.41 & 65.59 & $0.03(7.22)^{\star \star \star}$ \\
\hline Lulo & 2176 & 16 & 0.4188 & 10744 & 29.5 & 70.5 & $0.07(11.96)^{\star * *}$ \\
\hline Arracacha & 1084 & 15 & 0.4033 & 10741 & 24.47 & 75.53 & $0.06(10.31)^{\star \star \star}$ \\
\hline Granadilla & 2551 & 14 & 0.397 & 7663 & 44.02 & 55.98 & $0.01(0.78)$ \\
\hline Pear & 2120 & 15 & 0.3552 & 15033 & 18.6 & 81.4 & $0.04(6.71)^{\star \star \star}$ \\
\hline Tomato & 1412 & 20 & 0.3457 & 11395 & 32.33 & 67.67 & $-0.01(0.71)$ \\
\hline $\begin{array}{l}\text { Passion } \\
\text { Fruit }\end{array}$ & 1695 & 19 & 0.3378 & 6454 & 24.85 & 75.15 & $0.04(3.39)^{\star \star \star}$ \\
\hline Papaya & 1075 & 17 & 0.3083 & 8524 & 25.33 & 74.67 & $0.01(1.3)$ \\
\hline Pumpkin & 638 & 18 & 0.241 & 7755 & 19.03 & 80.97 & $0.22(10.53)^{\star \star \star}$ \\
\hline $\begin{array}{l}\text { Tree } \\
\text { tomato }\end{array}$ & 1493 & 13 & 0.2164 & 5590 & 23.92 & 76.08 & $-0.01(0.67)$ \\
\hline $\begin{array}{l}\text { Chili pep- } \\
\text { per }\end{array}$ & 2037 & 6 & 0.1979 & 4508 & 15.24 & 84.76 & $-0.22(4.51)^{\star \star \star}$ \\
\hline Borojó & 3473 & 5 & 0.1776 & 4000 & 14.53 & 85.48 & $-0.06(0.54)$ \\
\hline Curuba & 1133 & 15 & 0.1765 & 4591 & 18.25 & 81.75 & $0.07(3.58)^{\star \star \star}$ \\
\hline
\end{tabular}

Notes: ${ }^{*} p<0.1,{ }^{\star \star} p<0.05,{ }^{* \star *} p<0.01$. Table $A 2$ shows the 73 crops for which we have price information are mostly for basic consumption. Most of them are transitory fruits and crops with high relevance for the agricultural production of Colombia representing $61.85 \%$ of the planted area of the country. The more important crops in terms of planted area and number of agricultural units that produce them are the Plantain and Coffee. This is also evidenced of the percentage of assisted agricultural units that cultivate them. Total States and Mean Price are obtained from states with price and crop production information. Percentage area planted, Total agricultural units, percentage agricultural units with or without technical assistance. The difference in average yield is calculated as the difference in the value of production per hectare between agricultural units with technical assistance and agricultural units without technical assistance. Absolute value of $\mathrm{t}$ statistics is presented in parenthesis. 


\begin{tabular}{|c|c|c|c|c|c|c|c|}
\hline Crops & $\begin{array}{l}\text { Mean } \\
\text { price } \\
\text { (COP } \\
\text { per kg) }\end{array}$ & $\begin{array}{l}\text { Total } \\
\text { states }\end{array}$ & $\begin{array}{c}\text { Percentage } \\
\text { area } \\
\text { planted }\end{array}$ & $\begin{array}{l}\text { Total agri- } \\
\text { cultural } \\
\text { units }\end{array}$ & $\begin{array}{l}\text { Percentage agri- } \\
\text { cultural units } \\
\text { with technical } \\
\text { assistance }\end{array}$ & $\begin{array}{c}\text { Percentage agricul- } \\
\text { tural units without } \\
\text { technical assis- } \\
\text { tance }\end{array}$ & $\begin{array}{l}\text { Difference in } \\
\text { average yield }\end{array}$ \\
\hline $\begin{array}{l}\text { Green } \\
\quad \text { onion }\end{array}$ & 903 & 20 & 0.1383 & 7745 & 19.33 & 80.67 & $-0.15(11.56)^{\star \star \star}$ \\
\hline Ulluco & 932 & 3 & 0.1235 & 2259 & 28.29 & 71.71 & $0.11(9.44)^{\star \star \star}$ \\
\hline String bean & 1439 & 20 & 0.1197 & 3861 & 39.55 & 60.45 & $0.08(5.56)^{\star \star \star}$ \\
\hline Onion & 929 & 18 & 0.1159 & 7839 & 18.8 & 81.2 & $-0.05(2.36)^{\star \star}$ \\
\hline Strawberry & 3996 & 12 & 0.1037 & 3689 & 30.2 & 69.8 & $0.01(0.52)$ \\
\hline Peach & 2515 & 3 & 0.0925 & 2434 & 22.47 & 77.53 & $-0.51(3.49)^{\star \star \star}$ \\
\hline Lettuce & 1268 & 16 & 0.0874 & 2136 & 26.03 & 73.97 & $0.12(4.64)^{\star \star \star}$ \\
\hline Plum & 3934 & 7 & 0.0856 & 2577 & 13.62 & 86.38 & $-0.09(2.4)^{\star \star}$ \\
\hline Gulupa & 1016 & 1 & 0.0837 & 2055 & 39.22 & 60.78 & $0.01(1.43)$ \\
\hline Feijoa & 3359 & 3 & 0.0713 & 1371 & 15.17 & 84.83 & $0.03(2.31)^{\star \star}$ \\
\hline Watermelon & 680 & 11 & 0.0685 & 1136 & 13.2 & 86.8 & $0.01(1.08)$ \\
\hline Carrot & 827 & 18 & 0.0616 & 2171 & 21.1 & 78.9 & $-0.01(0.32)$ \\
\hline Pitahaya & 5432 & 5 & 0.0596 & 1723 & 44.86 & 55.14 & $-0.01(0.86)$ \\
\hline Parsley & 2882 & 7 & 0.0593 & 2256 & 28.99 & 71.01 & $0.02(1.66)^{*}$ \\
\hline Broad bean & 913 & 6 & 0.0537 & 1345 & 18.29 & 81.71 & $-0.08(2.19)^{\star \star}$ \\
\hline Coriander & 2335 & 18 & 0.0491 & 2057 & 26.59 & 73.41 & $-0.07(2.52)^{\star \star}$ \\
\hline Melon & 1567 & 10 & 0.0488 & 902 & 14.63 & 85.37 & $-0.04(3.89)^{\star \star \star}$ \\
\hline Grape & 3143 & 11 & 0.0482 & 822 & 30.66 & 69.34 & $0.03(2.29)^{\star \star}$ \\
\hline Zapote & 1409 & 5 & 0.0469 & 1113 & 13.12 & 86.88 & $0(0.05)$ \\
\hline Garlic & 4512 & 10 & 0.0448 & 1198 & 18.03 & 81.97 & $-0.06(1.56)$ \\
\hline Cabbage & 520 & 16 & 0.044 & 1255 & 27.57 & 72.43 & $0.16(5.47)^{\star \star \star}$ \\
\hline Uchuva & 2570 & 7 & 0.043 & 1262 & 19.81 & 80.19 & $-0.02(1.01)$ \\
\hline Pepper & 1464 & 16 & 0.04 & 1213 & 24.98 & 75.02 & $0.12(4.73)^{\star \star \star}$ \\
\hline Badea & 1142 & 6 & 0.035 & 1177 & 40.78 & 59.22 & $-0.26(5.25)^{\star \star \star}$ \\
\hline Fig & 3124 & 5 & 0.0331 & 855 & 16.14 & 83.86 & $0.07(0.86)$ \\
\hline $\begin{array}{l}\text { Potato } \\
\text { criolla }\end{array}$ & 1164 & 13 & 0.027 & 1308 & 16.13 & 83.87 & $-0.26(2.14)^{\star \star}$ \\
\hline Beetroot & 794 & 12 & 0.023 & 639 & 30.36 & 69.64 & $0.02(0.92)$ \\
\hline Pear & 1512 & 4 & 0.0227 & 960 & 5.52 & 94.48 & $-0.01(1.05)$ \\
\hline Cauliflower & 1647 & 14 & 0.0223 & 853 & 26.03 & 73.97 & $0.17(4.1)^{\star \star \star}$ \\
\hline Cucumber & 853 & 11 & 0.018 & 343 & 27.7 & 72.3 & $0.44(10.77)^{\star \star \star}$ \\
\hline Chard & 1034 & 11 & 0.018 & 530 & 27.74 & 72.26 & $-0.18(2.64)^{\star \star \star}$ \\
\hline Zucchini & 1090 & 5 & 0.0144 & 280 & 26.07 & 73.93 & $0.06(0.69)$ \\
\hline Green fig & 2289 & 1 & 0.0135 & 149 & 20.13 & 79.87 & $0(0.34)$ \\
\hline $\begin{array}{l}\text { Brussels } \\
\text { sprouts }\end{array}$ & 1233 & 3 & 0.0122 & 84 & 32.14 & 67.86 & $-0.05(0.68)$ \\
\hline
\end{tabular}


(Continued)

\begin{tabular}{|c|c|c|c|c|c|c|c|}
\hline Crops & $\begin{array}{l}\text { Mean } \\
\text { price } \\
\text { (COP } \\
\text { per kg) }\end{array}$ & $\begin{array}{c}\text { Total } \\
\text { states }\end{array}$ & $\begin{array}{l}\text { Percentage } \\
\text { area } \\
\text { planted }\end{array}$ & $\begin{array}{l}\text { Total agri- } \\
\text { cultural } \\
\text { units }\end{array}$ & $\begin{array}{l}\text { Percentage agri- } \\
\text { cultural units } \\
\text { with technical } \\
\text { assistance }\end{array}$ & $\begin{array}{l}\text { Percentage agricul- } \\
\text { tural units without } \\
\text { technical assis- } \\
\text { tance }\end{array}$ & $\begin{array}{l}\text { Difference in } \\
\text { average yield }\end{array}$ \\
\hline Apple & 2310 & 3 & 0.011 & 422 & 9.95 & 90.05 & $0.03(0.75)$ \\
\hline Eggplant & 1090 & 9 & 0.0098 & 494 & 14.98 & 85.02 & $-0.06(0.77)$ \\
\hline Broccoli & 1506 & 8 & 0.0064 & 412 & 24.03 & 75.97 & $0.12(2.01)^{\star \star}$ \\
\hline Leek & 2140 & 4 & 0.0064 & 235 & 30.64 & 69.36 & $0.06(0.79)$ \\
\hline Celery & 964 & 12 & 0.0057 & 487 & 25.26 & 74.74 & $0.11(3.01)^{\star \star \star *}$ \\
\hline Radish & 2093 & 7 & 0.0024 & 133 & 30.08 & 69.92 & $-0.02(0.26)$ \\
\hline Cidra & 359 & 1 & 0.0024 & 65 & 23.08 & 76.92 & \\
\hline Spinach & 1669 & 1 & 0.0004 & 9 & 22.22 & 77.78 & \\
\hline
\end{tabular}

\section{Appendix 3. 2SLS Robustness checks}

\begin{tabular}{|c|c|c|c|}
\hline & $\begin{array}{c}1 \\
\text { ETC + Bartik (Median) }\end{array}$ & $\begin{array}{c}2 \\
\text { ETC + Bartik (Weight) }\end{array}$ & $\begin{array}{c}3 \\
\text { ETC+ Planting Cost }\end{array}$ \\
\hline \multirow[t]{2}{*}{ Technical assistance } & $0.465^{\star \star \star}$ & $0.511^{\star \star \star}$ & $0.561^{\star \star \star}$ \\
\hline & $(0.052)$ & $(0.051)$ & $(0.053)$ \\
\hline \multicolumn{4}{|l|}{ Controls } \\
\hline \multirow[t]{2}{*}{ Size of agricultural units } & $-0.033^{\star \star \star}$ & $-0.036^{\star \star *}$ & $-0.009^{\star \star}$ \\
\hline & $(0.003)$ & $(0.003)$ & $(0.005)$ \\
\hline \multirow[t]{2}{*}{ Permanent jobs } & -0.000 & -0.000 & $-0.004^{\star \star *}$ \\
\hline & $(0.000)$ & $(0.000)$ & $(0.001)$ \\
\hline \multirow[t]{2}{*}{ Machinery Tenure } & -0.005 & -0.007 & $-0.039^{\star \star \star}$ \\
\hline & $(0.005)$ & $(0.005)$ & $(0.003)$ \\
\hline \multirow[t]{2}{*}{ Area agricultural infrastructure } & $-0.003^{\star \star \star}$ & $-0.004^{\star \star \star}$ & -0.000 \\
\hline & $(0.001)$ & $(0.001)$ & $(0.000)$ \\
\hline \multirow[t]{2}{*}{ Percentage men in households } & $0.020^{\star \star \star}$ & $0.020^{\star \star \star}$ & $0.021^{\star \star \star}$ \\
\hline & $(0.006)$ & $(0.006)$ & $(0.006)$ \\
\hline \multirow[t]{2}{*}{ Average household size } & $-0.001^{\star \star}$ & $-0.001^{\star \star}$ & $-0.012^{\star \star \star}$ \\
\hline & $(0.000)$ & $(0.000)$ & $(0.004)$ \\
\hline \multirow[t]{2}{*}{ Average education in household } & -0.001 & -0.001 & -0.000 \\
\hline & $(0.001)$ & $(0.001)$ & $(0.001)$ \\
\hline \multirow[t]{2}{*}{ Average age in household } & 0.000 & 0.000 & -0.001 \\
\hline & $(0.000)$ & $(0.000)$ & $(0.001)$ \\
\hline \multirow[t]{2}{*}{ Work force } & $-0.022^{\star \star}$ & $-0.022^{\star \star}$ & $-0.001^{\star \star \star}$ \\
\hline & $(0.011)$ & $(0.011)$ & $(0.000)$ \\
\hline
\end{tabular}


(Continued)

\begin{tabular}{|c|c|c|c|}
\hline & $\begin{array}{c}1 \\
\text { ETC }+ \text { Bartik (Median) }\end{array}$ & $\begin{array}{c}2 \\
\text { ETC + Bartik (Weight) }\end{array}$ & $\begin{array}{c}3 \\
\text { ETC+ Planting Cost }\end{array}$ \\
\hline \multirow[t]{2}{*}{ Percentage men head of household } & $-0.010^{\star \star \star}$ & $-0.011^{\star \star \star}$ & 0.000 \\
\hline & $(0.004)$ & $(0.004)$ & $(0.000)$ \\
\hline \multirow[t]{2}{*}{ Average education head of household } & -0.000 & -0.000 & $-0.022^{\star \star}$ \\
\hline & $(0.001)$ & $(0.001)$ & $(0.011)$ \\
\hline \multirow[t]{2}{*}{ Average age head of household } & $-0.001^{\star \star \star}$ & $-0.001^{\star \star \star}$ & $-0.001^{\star \star \star}$ \\
\hline & $(0.000)$ & $(0.000)$ & $(0.000)$ \\
\hline Hansen J Statistic $P$ value & 0.7075 & 0.844 & 0.278 \\
\hline Vereda fixed effects & Yes & Yes & Yes \\
\hline Number of veredas (Clusters) & 14637 & 14637 & 14748 \\
\hline $\mathrm{N}$ & 188706 & 188706 & 191588 \\
\hline
\end{tabular}

Notes: Standard errors clustered by vereda level. In columns 1 and 2, we use the median and weighted average planting cost for the same crops in other states. In the case of the weighted average, we use importance weights according to the similitude of the crops' composition between the state in which a unit is located and any other state. In column 4 , we use agricultural unit own plating $\operatorname{cost}^{*}{ }^{*} p<0.1,{ }^{\star \star \star} p<0.01$. 


\section{Appendix 4. Robustness coffee production}

\begin{tabular}{|c|c|}
\hline & Without major coffee producers \\
\hline \multirow[t]{2}{*}{ IV } & $0.778^{\star \star \star}$ \\
\hline & $(0.099)$ \\
\hline \multirow[t]{2}{*}{ ATE } & $0.6921^{\star \star \star}$ \\
\hline & $(0.0235)$ \\
\hline \multirow[t]{2}{*}{ ATT } & $1.2674^{\star \star \star}$ \\
\hline & $(0.0456)$ \\
\hline \multirow[t]{2}{*}{ ATUT } & $0.4261^{\star \star \star}$ \\
\hline & $(0.0153)$ \\
\hline \multirow[t]{2}{*}{ MPRTE: $P+\alpha$} & $0.9938^{\star \star *}$ \\
\hline & $(0.035)$ \\
\hline \multirow[t]{2}{*}{ MPRTE: $P(1+\alpha)$} & $0.8605^{\star \star \star}$ \\
\hline & $(0.0306)$ \\
\hline Observations & 146,220 \\
\hline
\end{tabular}

Notes: Standard errors are calculated with bootstrap (100 repetitions). Control variables not reported in this table, but included in estimations, are agricultural production unit characteristics and characteristics of households within the agricultural unit. ${ }^{* \star *} \mathrm{p}<0.01$. 